\title{
Fiscal Federalism and Local Government Finance in Nigeria
}

\author{
Ejikeme Nonso $\mathrm{Alo}^{1, *}$
}

\author{
${ }^{1}$ Department of Political Science, Redeemers University, Nigeria \\ *Correspondence: Ejikeme Nonso Alo, Department of Political Science, Redeemers University, 4, Benson Anorue \\ Street Ajao Estate Isolo Lagos State, Nigeria. E-mail: ejikemenonso@yahoo.com
}

Received: June 1, 2012

Accepted: August 19, $2012 \quad$ Online Published: September 28, 2012

doi:10.5430/wje.v2n5p19

URL: http://dx.doi.org/10.5430/wje.v2n5p19

\begin{abstract}
Fiscal federalism deals with the sharing of resources in a federated nation. Over the years problems about local government finance have become an important aspect of intergovernmental relations. Constitutionally, local government is the third tier of government which exists as an independent entity, possessing some degree of autonomy and sovereignty. However, its capability to perform its constitutionally mandated functions is beleaguered by the problem of inadequate revenue. In Nigeria, a number of factors have contributed to the financial setback experienced by most local governments and these include: overdependence on allocations from state and federal governments which in most cases are withheld by the same federal and state governments; lack of fiscal autonomy; creation of non-viable local governments, among others. The aim of this paper is to examine the problems of the local government in Nigeria, especially concerning its financial limitations, necessitated by the unequal share of resources, imbalance revenue-sharing formulae and lack of fiscal autonomy in the operations of the local government in Nigeria.
\end{abstract}

Keywords: Fiscal federalism, Local government, Autonomy, Finance

\section{Introduction}

The concept of local government simply implies government at the grass root level. The local government is the most critical and important level of government because it deals directly with the citizens of a particular state. The local government is a formal organization set up by law, and it has a degree of autonomy to perform certain constitutional functions. Local governments are created with the expectation of delivering services within their jurisdictions. Any state or nation aspiring for development must ensure that there is the decentralization of power and functions to lower tiers of government in order to accommodate the interest of individuals at the grass root level. In most federal systems of government there is the existence of local authorities or local government; and their constitution allows for decentralizing power and functions as well as finance down to grass root governance.

Historically, the local government in Nigeria has faced a lot of problems; it has been beset by limitations ranging from lack of autonomy, dictatorial attitude of the central government, and financial limitations, of course, among others. The native administration set up by the British colonial administration lacked the capacity to function without incessant interruption from the central colonial authority. The establishment of regionalism in 1945 and the quasi-federal system in 1951 set the pace for a federal structure in the country. Yet, while during this period there was the existence of local authorities, their functions(rights) were not clearly defined but until 1976. It was the 1976 local government reform that set the pace for the establishment of an 'independent' third tier of government in Nigeria.

Indeed, finance is a necessity for any organization with responsibilities and functions to perform. The survival and sustainability of local government largely depends on its finance(Bello-imam, 2007). According to the 1979 constitution, there were two major sources of local government revenue and these included the internal and external sources. The internal sources included poll tax or community tax, property tax, user fees and benefit tax, and others; the external sources of revenue for local government included fiscal transfers from the central government and loans. Although these requirements are stipulated in the Nigerian constitution up till today, in reality and in practice both the state and central government shave exhibited a nonchalant attitude towards fiscal transfers to the local government. More so, most of the internal sources of generated revenue by the local government are hijacked by the 
central and state governments, leaving the local government with multiple functions but limited means for proper implementation of such functions.

\section{Conceptual clarification}

An analysis on local government without demystifying its conceptual meaning would lead to mental paralysis instead of enlightenment stimulation. It is imperative to define the concept, local government. Abubakar (1993) pointed out that local government was consensually regarded as government or administrative units closest to the people or the grass roots. Also, Robson(1949) argued that the local government is seen as a territorial non-sovereign community possessing the legal rights and necessary organization to regulate its own affairs. According to the United Nations office for public administration, local government is a political sub-division of a nation which is constituted by law and has substantial control of local affairs including the power to impose taxes and require labor for prescribed purposes.

From the above definitions, it is clear that local governments are local entities, with defined territories, discretionary power, functions, responsibilities and, most importantly, autonomy. In principle, local governments are created with the expectation that its administrative and political officers will exert influence and control the decision-making process at the grass root level without interruptions from higher tiers of government. In practice, however, as evidenced in the Nigerian case, the local governments have been subjected to mere agents of the federal and state governments.

Any state that pursues development and cherishes the enthronement of democracy as the guiding principle of its government must ensure that there is the devolution of power in the form of local administration or local government. Aborisade (2006) contended that local government represented veritable foci of socio-economic development and democratic consolidation because it provided the medium through which government extended its policies and implemented such policies and programmes across the federation. More so, local government ensures for integrative participation in politics: since elections are conducted in local government areas, they are testing grounds for the local administrators who will become the national leaders in a near future.

\section{The concept of fiscal federalism}

In any federal system, an important aspect of interrelationship between the centre and the sub-units is finance. In most federal systems there are usually three levels of government: federal, state and local governments. Equity in resource sharing among the three levels of government has become a fundamental problem in the federal systems. Although the constitution in most cases stipulates the functions of each tier of government, and areas which they can exert influence, there is still every tendency that the rights of the lower tiers of government, and most especially the local government, are trampled upon by the central, as well as the state, government. Fiscal federalism does involve how the resources of a given state are equitably allocated and how the powers and functions of each tier of government are shared.

There are certain focal points when in the discussion of fiscal federalism, and they are the questions:

(i) What are the powers of the central government and its sub-units to generate revenue?

(ii) What is the relative importance of the proportion of total government revenue that is actually utilized by the central, state and local governments, regardless of how the total revenue is raised?

(iii) What is the role of state and local governments in raising revenues and how is their spending regarded as good implication of the degree of decentralization.

Fiscal federalism in the Nigerian context involves the allocation of expenditure and taxation powers shared among the federal, state and local governments. Akindele and Olaopa(2002) held that fiscal federalism was deeply rooted in the federal system of government. It involves the financial relationship among the three tiers of government. It is the process through which the Nigerian federal government shares the resources of the nation through the transfer of funds such as grants to the state and local governments. In Nigeria's political experience, the local government has not benefited from this system of resource sharing. Consequently, this unfair treatment has undermined the capacity of the local government to act effectively as an independent third tier of government constitutionally vested with certain rights and responsibilities. 


\section{An overview of the evolution of local government in Nigeria}

Prior to the colonial era, there was the existence of local administration having definite political institution in different traditional societies. This made the British colonial government to introduce the policy of indirect rule(Bello-imam, 2007,p. 26). The indirect rule system became the form of local administration in the indigenous societies during the colonial era. Native authority, native treasury and native courts were also established to formally represent the local administration structure. Not with standing, because it was controlled directly by the British colonial administration the colonial local administration was not recognized as an independent entity. In particular, the colonial administration during the colonial era lacked legislative powers, indeed; the British resident directly supervised the traditional ruler who was in direct contact with the people. Subsequently, the Richard constitution of 1946 through its introduction of regionalism enhanced the powers of the local authorities and laid the foundation for the local government reform of1976. In the 1950's, under the Macpherson constitution, Nigeria began practicing a quasi-federal system of government which entailed the division of the country into various regions. It was the regional division that led to the emergence of the local government in the country; the regions began to adopt diverse local government systems.

In an attempt to ensure that there was a stable and uniform system of local government across the Nigerian federation, the federal government embarked on reforms that eliminated the old system of local government and institutionalized a more stable system for local government growth and development in the country in 1975. The resultant reform involved the establishment of a uniform structure of local government vested with certain powers and functions. Prior to the reform, the regional or state government had the power to pass legislation that ensured the establishment, composition, structure and finance of the local government. This system was abolished in 1979 and the local government became a distinct tier of government. At present, local governments in Nigeria have derived their powers from the constitution and not from the state House of Assembly.

Despite the reform and constitutional changes, the interaction between the federal, state and local governments have been characterized by conflict and competition. The central and state governments have hijacked certain functions which are preserved for the third tier of government. Local government autonomy, independence and sovereignty have become questions of controversy in intergovernmental relations in the country, specifically. Thus, having examined the historical evolution of local government from the colonial era till date it is pertinent to discuss some of the major challenges of local government in Nigeria.

\section{General problems of local government in Nigeria}

With certain functions devolved to it in the Nigerian constitution, the local government is an independent sovereign entity. The local government has the discretionary power to act within its jurisdiction without unnecessary interference from the federal and state tiers of the government. Indeed, the local government is created as independent institution to guarantee democratic participation in the governance of the nation. In this regard, electoral competition is narrowed down to the grass root, allowing for mass participation of the citizens in the governmental process. As established in the 1976 local government reform, another major consideration for the creation of the local government is for it to act as an agent of local freedom and autonomy. In other words, a local government has the power to act independently, deriving its powers from the constitution.

Furthermore, local governments act as agents of national integration. The devolution of power from the centre to the local administrations implies that policies initiated by the central government can be implemented in the various local government areas. It also implies that a local government serves as a means of protecting the diverse socio-cultural heritage of the multi-ethnic groups in the federation. And the cardinal purpose of the local creation is to provide adequate and efficient social welfare services to the people. Against this background of the reason for the creation of local government, the problems and challenges of local government in Nigeria will better be understood.

\subsection{Financial problems}

How can a local government in the country ensure growth and development at the grass root when itis financially handicapped? How can the local government perform when its revenue (from the external and internal sources) is not adequate to undertake its constitutional functions? To be sure, there are but just a few local governments in Nigeria that could survive without financial allocations from the central government. Unfortunately, the sections of the Nigerian constitution which falls under the exclusive power of the various local governments to generate revenue internally are in reality usurped by the central government. Consequently, most local governments in Nigeria depend solely on external allocation, which is a constitutional right too. However, the external allocations 
in most cases are not sufficient to solve the needs of the 774 local government areas in the country. In fact, the federal and state governments do deliberately withhold the funds for local governments for their own pecuniary benefits.

\subsection{Local autonomy}

Autonomy simply implies independence and freedom. Local autonomy therefore means that since the local government is identified as an independent third tier of government in a country its capacity to perform efficiently depends on the level of freedom it enjoys. Local governments in Nigeria are not effective and efficient due to the fact that some of its vital functions are encroached on by the central and state governments. The constant interference of the higher tiers of government on the powers and functions of the local government makes the attainment of an autonomous local government an illusion and unachievable in the Nigerian polity. Without doubt, from the colonial administration till date the local government in the country has not experienced full autonomy.

Local governments should be allowed to undertake actions and accept responsibilities for their actions, if they are to perform effectively their functions. The state house of assembly should not usurp and exercise supervisory power over local governments; rather, the legislative arm of the local government, the council, should be empowered to supervise the local government businesses. Notwithstanding, local government autonomy does not translate to equating the powers of the federal and local governments. The central government yet has the right to monitor the activities of the lower tiers of government and ensure adherence and compliance with standards and best practices in governance at the local level across the country. In fact, the central government should strictly and meticulously enforce compliance to governance standards in the local administrations. However, it should not neglect the functional competence of the lower tier of government (Bello-imam, 2007).

\subsection{Manpower or personnel}

Most local governments in Nigeria lack the adequate manpower to deliver on their functions effectively. The quality of staffs in most local governments is below standard. A number of steps have been taken in other to alleviate this problem, such as the establishment of the local government service commission (LGSC) to supervise the appointment, promotion and discipline of the local government staffs.

\subsection{Excessive control}

Another worrisome problem experienced by most local governments in Nigeria is the excessive control by the state governments. A state government determines and dictates the spending limits of the local governments within its territorial boundary. This is why the delions rule will advocate that the life and death of a local government lies on the desk of the state house of assembly, since the state government assigns certain responsibilities and functions to the local government without adequate financial backing for the performance of such functions and responsibilities. Thus, the local government in Nigeria really exists as an extension of state and federal governments than as an independent entity.

\section{A comparative analysis of fiscal relations on the global scene}

In the global arena fiscal relations in federal systems vary from country to country. In his opinion, Bello-imam(2007) asserted that the share of resources varied from country to country and this was shaped by the historical antecedents and operations of its federal system. However, that is not to say that fiscal relations do not exist in unitary government systems. For instance, in Britain $44.2 \%$ of the revenue of local authorities in England and Wales comes from federal grants while $20.9 \%$ comes from user fees and benefit charges, sales and interest receipts, and the remaining $34.9 \%$ comes from rates (Ogbuisi, 2007). From this analysis, although a reasonable percentage of the revenues of most local authorities in Britain come from the central government, it is interesting to note that a huge percentage of about $55.8 \%$ of the local government revenues are derived internally. The meaning of this is that the local authorities are given a degree of autonomy to adequately make use of the resources within their own sphere of influence.

The same goes for the United States where the local authorities enjoy financial transfers of about $37.2 \%$ while $29.2 \%$ of their revenues come from property tax and user fees and benefit charges account for about $33.6 \%$. The meaning of this is that $62.8 \%$ of the local government revenue comes from internal sources (Bello-imama, 2007). It also implies that there is a degree of financial freedom for the government at the grass root. In contrast, the share of resources in the Nigerian case is quite different. Fundamentally, the local governments in Nigeria are not efficiently financed. Unlike what is attainable in the United States and Britain where local authorities are given the discretion to 
engage in generating revenues, in the Nigerian context the federal and state governments hijack a bulk of resources meant for local administration as well as powers for the local authorities to generate revenue. Consequently, this situation thus ensured a high dependency on federal and state allocations which are not efficient to satisfy the needs of the 774 local government areas in the country.

\section{Fiscal federalism and local government finance in Nigeria}

Finance is a necessity for the existence of any organization or institution, no doubt. Local governments are autonomous units within a federation with certain statutory rights and responsibilities, an agent of decentralization and democratic stability; therefore, the place of finance local government administration is really crucial. Indeed, the study of the Nigerian local government system has become a fundamental issue, especially because of its financial challenges. Various constitutions have surfaced in Nigeria's political history and these constitutions have helped to shape the status of local government in the country. In 1979, the constitution recognized the local government as an independent third tier of government in the country and vested with the power to generate its own revenue internally. And there was yet another principal aspect of revenue generation for the Nigerian local government: it bothered on the fact that in all federal arrangements the national resources are shared among the central, state and local governments.

Moreover, different regimes have devised different revenue allocation formulae in Nigeria's political history. Between 1976 and 1992 the revenue allocation by the federal government to the local government increased from 10\% to $20 \%$ of the federation account; and $10 \%$ of the internally generated revenue of the state was to accrue to the local government too (Bello-imam, 2007). Constitutionally, local governments are further empowered to generate revenue internally through the following means: levying of taxes, such as poll tax, property tax, user fees, benefit charges, and others.

To have a closer understanding of the nature, pattern and features of fiscal relations between the local government and the other higher tiers(federal and state) of government in the country yet, it is imperative to consider the various sources of local government revenue in Nigeria.

\section{Sources of local government revenue in Nigeria}

The source of local government revenue implies the means through which most local governments in Nigeria generate revenues to ensure that they perform their constitutional functions. There are two major sources of local government revenue in Nigeria: (i) internally generated revenue, which is revenue generated within the local government area of administration and it entails local tax or community tax, poll tax, or tenement rates, user fees and loans; and (ii) externally generated revenue, which refers to the local government funds generated outside the local government area of administration. However, it is an unfortunate development whereby the revenue sources for local governments are mainly fiscal transfers and loans to the local governments.

\section{Fiscal transfers and revenue allocation in Nigeria}

The emphasis of this paper is on the financial challenges of local government in Nigeria, examining it and evaluating the various means of revenue generation by the local governments. And the study is to consequently highlight problems encountered in the sharing of resources between the lower tier of government and the other higher tiers as well as highlight the efficacy of the internally generated revenues by local governments, in Nigeria. Fiscal transfers to local governments are direct financial allocations from the central government or state government to the local government. It cannot be over-emphasized that financial transfers have most significantly defined central/local government fiscal relations worldwide. In some countries, this financial transfers are referred to as intergovernmental transfers, and in Nigeria it is called grants or statutory allocations. The transfer of funds from the central government to the local administrations is premised on certain considerations. Most important of the considerations concerns the relative reluctance of the federal government to vacate some certain revenue fields for the local governments. The federal government is so reluctant even when such revenue fields are within the jurisdiction of a local government.

Bello-Imam(2007) stated the reasons for fiscal transfers to include:

i) To compensate local governments having low fiscal capacity, especially those with a relatively inferior potentials for raising their own direct revenues; 
ii) To assist local governments to cope with emergencies;

iii) To control local expenditure with a view to ensuring compliance with national policies and standards; and

iv) To finance either wholly or partly the cost of services or development programmes which are for national development.

By 1976, the revenue allocation from the federal and state government to local governments in Nigeria took various forms ranging from grant-in-aid to the percentage and block grants. During this period the state government exhibited a nonchalant attitude towards fiscal transfers to the local governments. After a series of investigation, the Udoji-led committee in 1976 came up with a solution to address the issue of local government financing: the committee introduced a mandatory statutory allocation to the third tier of government. This decision was further strengthened by the 1979 constitution which gave power to the National Assembly to determine how the allocations to the local government should be made. The resolution was backed up with the Revenue Allocation Act of 1981 providing for both the federal and state governments to allocate $10 \%$ of their revenues to the local governments.

Despite these reforms the fiscal transfers in the Nigerian context has remained the most controversial and highly politicized issue in the country. Although different strategies have been adopted to ensure that there is a smooth relationship between the central and local government, the strategies have been futile and the problem of resource sharing has lingered. Fundamentally characterizing the central-local government fiscal relations is the lots of central (federal) executive interference on the revenue allocation formulae. The federal executive interference has, to be sure, rendered most of the local governments financially handicapped. Yet, the local government in the country is allotted a lot of functions and responsibilities in the Nigerian constitution. Can the local governments lean on internally generated revenues?

\section{The internal sources of local government revenue}

The financial problems confronting most local governments in Nigeria is, regrettably, not restricted to their external revenue sources; the challenges also concern the internal sources of revenue generation. Therefore, it is pertinent to examine the factors militating against the effectiveness of the internal sources of local government revenue in Nigeria. There is the rapid decline in the internal sources of local government revenue in Nigeria and the conversely relative increase in the local government functions. In this case, the functional requirements of local governments in Nigeria are not commensurate to their revenue status, especially the condition of their internally generated revenues. Also, the rapid increase in revenue allocation to the local government rather enhances the avenue to exploit the resources for grass root governance for private interests. Indeed, most state governments in the country usurp the vital sources of revenue of local governments, thus hijacking functions in the jurisdictions of the lower tier of government.

In particular, the state governments ensure that the local government does not exercise their powers of taxation on property. The internal sources of local government which includes poll tax or community tax, property tax, tenement taxes, user fees and benefit charges are not sustainable for the local governments to undertake their enormous tasks and responsibilities in their administrative area. An examination of the various internal sources of revenue generation will help to realize how entrenched has been the setback to local government finance and fiscal federalism in Nigeria.

\subsection{Poll tax or community tax}

This is a kind of tax paid by every eligible citizen within the society, whether such citizen enjoys government services or not (Bello-Imam, 2007). In Nigeria, male citizens above the age of eighteen are expected not to earn more than a specific level of income; and every citizen is under the Pay As You Earn (PAYE) tax regime. But the PAYE tax system is fraught with a limitation: most local governments do not have constant and trusted means to enforce the collection of tax dues. Another problem associated with the tax system is that the government does not allow the tax rate to rise in line with increase in incomes. For instance, in the 1970's, and up till date, the income levels of Nigerian individuals have risen tremendously but the poll tax rate has remained the same.

\subsection{Property or tenement tax}

If well exploited by local governments in Nigeria, the property tax is an important source of local government revenue. The property tax can yield the local administrations tremendous financial gains. Property tax accounted for 30 percent of local government expenses of about 20.6 billion pounds in the year 1982 in Great Britain, for instance. 
Certain local governments in Nigeria can even derive largest revenues from the property tax; those situated around industrial areas, such as in Lagos, Port Harcourt, to mention a few, can most advantageously exploit the property tax revenue source. Nevertheless, among the challenge about the property tax in the Nigerian experience is that it lacks popularity and the higher tiers of government (that is, federal and state governments) are reluctant in supporting local governments to effectively take advantage of the revenue source.

\section{The Problems of intergovernmental fiscal relations in Nigeria}

A further consideration of the financial predicaments of local governments in the Nigeria and the mode of resource allocation in the federation, even with historical exegesis, will help to establish the true financial position of local governments in the country. It is a well-known fact that the share of resources in the Nigerian federation is characterized by federal dominance. Despite the domination by the federal government, the political class constituting the federal government has been unable to map out a stable and generally acceptable means of resource allocation in the country.

Ogbuisi (2007) identified important problems associated with fiscal relations in Nigeria to include the problem of revenue allocation formulae. The problem of revenue allocation formulae have surfaced in Nigeria's historical experience several times. Past efforts to curb this problem involved past administrations setting up commissions to devise stable and acceptable revenue allocation formulae for the country. Indeed, the first of the commissions was established during the colonial era. The Philips on Commission of 1946 recommended two basic principles for the revenue allocation formulae: derivation and even development. Before Nigeria attained her independence, there were three commissions which arrived at different recommendations too. Hick-Philips on Commission of 1951 recommended the principle of need; Chick Commission of 1953 recommended the principle of fiscal autonomy; and Riesman Commission of 1958 came recommending the extent of service in the region, the responsibilities performed by each region, population and balanced development.

Furthermore, prior to Nigeria's independence there were basically three modes of revenue allocation. The three modes of revenue allocation included: (i) derivation; (ii) equity; and (iii) population. After independence, constant military intervention in the polity which led to political instability in the system brought series of other reforms, involving other committees such as the Dina Committee of 1968 and the Aboyade Committee of 1977. In 1979, the Dr Pius Okigbo-led Committee came up with certain recommendations and a new revenue-sharing formulae was adopted. The new formulae for sharing the government revenue is stated as following:

Federal government $-55 \%$

State government $-30 \%$

Local government $-8 \%$

Special funds $-7 \%$

Other subsequent administrations in the country, Nigeria, both military and civilian governments, embarked on various reforms, including the Buhari/Idiagbon, Babangida, and Abacha administrations, and others. Currently, the following formula is used in sharing government resources in Nigeria:

Population

Equity of states

Internal revenue

Land mass

Terrain and population density

The basic question is how can $8 \%$ of the nation's resources effectively solve the problems of and finance the 774 local government councils in the country? Local government, as noted earlier, is the closest level of government to the people and as such should be a focal point in the effort to transform a state and ensure its economic development. But with the so little support from the federal and state governments it is hardly possible that any transformation agenda and plan towards economic development will be realized in the country, where the local governments are mere establishments. Indeed, the local governments cannot undertake all the functions stated in section 7(1) of the 1999 constitution with peanuts allocation granted them by the federal government. Therefore, it is instructive that the basic problem of Nigerian local governments is not only their inability to raise funds internally but also due to both the inconsistency and inadequacy of revenue allocation to them as determined by the federal 
government.

\section{Fiscal control and the abrogation of local autonomy by higher tiers of government in Nigeria}

Fiscal control has become a problematic issue in intergovernmental fiscal relations in Nigeria. In this respect, the higher tiers of government have excessive control on the finance of the lower tier of government - that is, the local governments. In Nigeria, most state governments usually tend to control the funds of local governments. Ogbuisi (2007) argued that the problem of constant state intervention in the local government funding had a constitutional basis. According to the 1999 constitution of the federal republic of Nigeria, section 162 (5), it is stated that '...Any amount standing to the credit of the local government councils in the federation account shall be allocated to the states for the benefit of their local government councils in such terms and in such manners as may be prescribed by the state house of assembly...'Likewise, section 7(1) of the 1999 constitution holds that'...the finance, composition, functions, and structure of the local government in the federation is to be determined by the prescriptions of the state house of assembly...' This simply implies that the Nigerian local governments have no power on their own to determine how their affairs are run.

Okolie and Eze(2004)(cited in Ogbuisi, 2007) further observed that the funds which the state governments were supposed to share among the local governments were in reality directed to state projects. Corroborating, Nwokedi (2002) (cited in Ogbuisi, 2007) also held that the unrepentant attitude of the state governments towards exploiting the funds of local government became obvious when the federal government decided to allocate directly to the various local governments for the purpose of paying teachers in the states' employ. To be sure, the decision by the federal government would sideline the state governments' interests. The state governments, in response, went to court and challenged the decisions of the federal government. And fortunately, or unfortunately, the Supreme Court ruled in favor of the state governments stating that it was unconstitutional for the federal government to allocate finance directly to the local governments. The point being made here is that the state governments court appeal against the federal government decision was not just because of its unconstitutionality; it was due to the pecuniary goal of the state governments to continue the exploitation of local government funds (Ogbuisi, 2007).

\section{Conclusion and recommendations}

In conclusion, the issue of finance and fiscal relations between the higher tiers of government in Nigeria and the lower tier, the local governments, has become a principal setback to true transformation and real economic development in the country. For the local governments in Nigeria to perform effectively affecting the grass root Nigerian populace with the desired optimal impact there is the need for independence and certain degree of autonomy for the local administration. To achieve this, it is apparent that the federal and state governments must jointly reach a consensus on how their interactions with the local government tier will be moderated. This will further require that an independent and transparent committee that will comprise technocrats who are representatives from the 774 local government councils in the country be constituted. Of course, other parties in the committee will be state and federal government officials. The central objective of the independent committee will be to iron out the problems facing local government finance in the country. In addition, right from the onset of their business, the committee should resolve that their final decisions will not end as ordinary paper work, unlike with such previous experiences. They will embark on full implementation of the committee's resolution.

Furthermore, that the average Nigerian politician has no regard for the constitution is apparent given the nature of intergovernmental fiscal relations in the polity. When it is said the federal government has interfered in the affairs of the lower tiers, one asks mind who actually is the federal government? The federal government on this issue is not only a vague institution but specifically the Nigerian politicians in the government. Nigerian politicians have not learnt to play politics by the rules. While the constitution spells out the power of each tier and level of government,it is the responsibility of the actors within these political institutions, levels and tiers of government to adhere strictly to the provisions of the constitution.

Finally, the establishment of local government was due to the need to ensure that there is the decentralization of power, popular participation, national integration, effective communication or link between the center and the lower tier of government, as well as the provision of essential services to the localities. But constituting real financial setback to the attainment of the goals by the Nigerian local governments is the unequal and imbalance sharing of resources and the constant interference of the higher levels of government with the funds meant for the local government. Be that as it may, the local governments in Nigeria should not fold their hands waiting for help or aid 
from the federal or state governments. With the little available resources they generate, or can generate, internally the local government should initiate significant development programmes within their localities, however small the programmes may seem. Indeed, this will establish and assert their importance, relevance, and enhance their acceptance as legitimate third tier of government by the grass root people.

\section{References}

Aborisade., \& Aransi, O. (2006). State and local government in Nigeria: The changing scene. USA: Catawba Publishing Company.

Abubakar, H. I. (1993). Local government in development. In O. Aborisade, \& I. O. Aransi (Eds.), State and Local Government in Nigeria: The Changing Scene. USA: Catawba Publishing Company, p. 32.

Akindele, S. T., \& Olaopa. (2002). Fiscal federalism and local government finance in Nigeria. Retrieved from http://unpan1.un.org/intradoc/groups/public/documents/CAFRAD/UNPAN008121.pdf

Bello-Imam, I. B. (2007).The local government in Nigeria. Leed City University, Ibadan: College Press \& Publishers Limited.

Ogbuisi, A. F. (2007). Fundamentals of intergovernmental relations. Enugu, Nigeria: Academic Publishing Company.

Robson, N. (1949). Local government. In The Encyclopedia of Social Sciences (Vol1, No. 9, p. 574). 